\title{
KONSEP PENDIDIKAN HUMANIS DAN IMPLEMENTASINYA DALAM PROSES BELAJAR MENGAJAR
}

\author{
Nur Zaini* \\ * STIT Al Fattah, Siman, Lamongan
}

\begin{tabular}{|c|c|}
\hline INFO ARTIKEL & ABSTRAK \\
\hline & Abstract: Humanist education must be praxis in the teaching and learning process. So \\
\hline $\begin{array}{l}\text { Diterima: 22-01-2019 } \\
\text { Disetujui:23-01-2019 }\end{array}$ & $\begin{array}{l}\text { in its implementation, an educator must be a qudwah or a good example, by } \\
\text { promoting love and affection in the teaching process. Educators must be able to bring } \\
\text { up a sense of empathy, be able to provide motivation, foster an attitude of tolerance, }\end{array}$ \\
\hline Kata kunci: & combine feelings (learners' desires) with teaching material, and Educators with all \\
\hline $\begin{array}{l}\text { Konsep } \\
\text { Pendidikan Humanis } \\
\text { Implementasi }\end{array}$ & $\begin{array}{l}\text { humility are required to be transparent for any shortcomings. So as to create a good } \\
\text { pattern of multi-way communication (ways traffic communication) between educators } \\
\text { and students. }\end{array}$ \\
\hline
\end{tabular}

\begin{abstract}
Abstrak: Pendidikan humanis harus praksis dalam proses belajar mengajar. Maka dalam implementasinya, seorang pendidik harus menjadi qudwah atau teladan yang baik, dengan mengedepankan cinta dan kasih sayang dalam proses mengajar. Pendidik harus mampu memunculkan rasa empati, mampu memberi motivasi, menumbuhkan sikap toleransi, memposisikan sebagai teman belajar, menciptakan suasana belajar dialogis, mampu mengkombinasikan antara perasaan (keinginan peserta didik) dengan bahan pengajaran, dan Pendidik dengan segala kerendahan hati dituntut transparan atas segala kekurangan. Sehingga tercipta pola komunikasi multiarah (ways traffic communication) yang baik antara pendidik dan peserta didik.
\end{abstract}

\author{
Alamat Korespondensi: \\ Nur Zaini, \\ Pendidikan Agama Islam \\ STIT Al Fattah \\ Kompleks PP Al-Fattah, Desa Siman, Kecamatan Sekaran, Kabupaten Lamongan, Jawa Timur \\ E-mail:zensukses@gmail.com
}

Pendidikan merupakan masalah esensial dalam kehidupan manusia. Pendidikan menentukan baik atau buruknya sumber daya manusia. Jika pendidikan yang diperoleh seseorang memiliki kualitas yang baik, maka baik juga sumber daya manusia yang dimilikinya. Oleh karena itu, desain pendidikan selayaknya dipersiapkan secara matang sehingga hasil yang dicapai pun memuaskan (Syafi'i Ma'arif, 1991: 15). Pendidikan merupakan proses humanisasi atau biasa disebut dengan proses pemanusiaan manusia. Proses ini tidak sekedar yang bersifat fisik, akan tetapi menyangkut seluruh dimensi dan potensi yang ada pada diri dan realitas yang mengitarinya. Sebagaimana yang dikatakan H.A.R. Tilaar (2005:112), bahwa hakikat pendidikan adalah proses memanusiakan anak manusia, yaitu menyadari akan manusia yang merdeka. Manusia yang merdeka adalah manusia yang kreatif yang terwujud di dalam budayanya.

Namun menurut Sulaeman (2000: 81) pendidikan belum mampu mencapai titik idealnya yakni memanusiakan manusia. Menurutnya justeru sebaliknya yakni menambah rendahnya derajat dan martabat manusia. Makna pendidikan yang belum terealisasikan ini menurutnya terkait dengan situasi sosio-historis dan kondisi lingkungan yang materialis dan hedonis. Sebagai contoh, penjajahan Barat (kaum kolonialisme) terhadap bangsa Indonesia selama 3 abad lebih lamanya, ternyata membawa dampak terhadap pola pikir dunia pendidikan, yaitu munculnya masyarakat kelas "elit". Produk dari sistem pendidikan (Barat) terdesain untuk membentuk sebuah kelas yang tercerabut dari tradisi budaya dan moralnya. 
Argumentasi Sulaiman tersebut mengokohkan bahwa pendidikan yang berjalan masih belum humanis atau belum memanusiakan manusia (dehumanisasi). Dehumanisasi merupakan satu masalah mendasar dalam sistem pendidikan nasional. Pendidikan tidak lagi menghormati dan menghargai martabat manusia dan segala hak asasinya. Akibatnya, melalui proses pendidikan peserta didik tidak tumbuh dalam kemanusiaan sebagai subyek. Mereka justru menjadi korban dalam sebuah sistem yang memaksa mereka mengikuti aturan dalam sistem itu.

Terjadinya dehumanisasi pendidikan di hampir setiap jenjang pendidikan karena orientasi pendidikan sudah menjadi komoditas atau kepentingan bisnis semata. Kondisi itu menyebabkan proses pendidikan tidak hanya menjadikan Pendidik sebagai instruktur dan pawang semata, tetapi juga mengedepankan nilai kuantitas ketimbang nilai-nilai kemanusiaan dalam barometer pembelajaran. Dehumanisasi pendidikan saat ini yang mengarah pada kekerasan dan degradasi moral.

Di sisi lain, akibat pendidikan menjadi komoditas atau kepentingan bisnis semata, arah kebijakan pendidikan nasional pun sering berubah, yakni lebih mengedepankan aspek kuantitas ketimbang nilai-nilai humanisme (kemanusiaan). Contoh yang paling kongkret proses pembelajaran yang hanya diukur melalui ujian nasional (UN) untuk menentukan kelulusan seorang peserta didik (Wawan, 2008). Sehingga, Peserta didik hanya dikejar dengan target-target semata daripada pentingnya nilai etika dan estetika. Karena itu, tidak mengherankan jika saat ini, peran Pendidik pun berubah, dari peran sentral sebagai teman, menjadi peran yang bertindak sebagai "pawang" dan instruktur semata.

Pembelajaran tak lagi menarik. Suasana kelas yang mestinya menjadi ajang mengembangkan kreativitas dan eksplorasi diri, kini menjadi senyap karena yang ada adalah drilling soal-soal persiapan UN, latihan soal persis lembaga bimbingan belajar yang memang terlahir untuk menjadi ajang memecahkan soal. Seolah-olah dengan adanya UN, sekolah diajak melupakan tanggung jawab utamanya sebagai ajang pembentukan manusia. Pendidikan memang telah direduksi menjadi sangat pragmatis yang penting tujuan tercapai sementara prosesnya cenderung diabaikan.

Peserta didik telah menjadi obyek demi kepentingan ideologi, politik, industri dan bisnis. Salah satu contoh paling nyata adalah asumsi bahwa apa yang diajarkan jauh lebih penting dari siapa yang diajar. Prestasi pendidik juga diukur dari nilai yang didapat peserta didiknya. Pendidik sebagai pendidik tidak mampu menghentikan dehumanisasi ini karena pendidik sendiri terjebak sebagai obyek dalam sistem pendidikan nasional.

Makin jarang dijumpai pendidik yang (humanis) mengajar dengan cinta kasih. Pendidik yang memberikan sepenuh waktu dan hidupnya untuk kesejahteraan hidup peserta didiknya. Pendidik yang merasa gembira ketika peserta didiknya berhasil dan pendidik yang merasa bersedih ketika menyaksikan peserta didiknya gagal dalam mencapai tujuan dan cita-citanya. Pendidik yang demikian hanya akan lahir dalam suasana pembentukan yang memang mengedepankan aspek pemanusiaan dan pembudayaan.

Apapun bentuknya, dehumanisasi (kekerasan) dalam pendidikan harus dicegah. Untuk mencegahnya, norma agama, budaya, dan nilai-nilai kemanusiaan perlu ditanamkan dalam diri seseorang melalui pendidikan nilai (afektif) yang humanis. Norma agama (Islam) amat berarti dalam membersihkan kesadaran kemanusiaan; kasih sayang (QS. 48: 29), Pemaaf (QS. 2: 187), saling menolong (5: 2), mengutamakan perdamaian, bukan kekerasan serta pengerusakan (QS. 2: 220) menghormati hak orang lain (QS. 22: 40) tidak mencela dan menghina (QS, 49: 11), mencuri atau bahkan saling membunuh( QS. 5: 38). Pendek kata, ajaran Islam sarat dengan pendidikan afektif dan humanis, yang dapat digunakan sebagai alternatif upaya menghentikan perilaku kekerasan dan perilaku-perilaku dehumanisasi lainnya dalam pendidikan. Selain itu, pendidikan humanis harus disetting sedemikian rupa agar dapat dimplementasikan dalam proses pembelajaran, sehingga tidak hanya menjadi konsep belaka.

\section{PEMBAHASAN}

\section{Pengertian Humanisme}

Istilah ini berasal dari bahasa Inggris yaitu humanism. Humanisme berarti menganggap individu rasional sebagai nilai tertinggi, menganggap individu sebagai sumber nilai terakhir, dan mengabdi pada pemupukan perkembangan kreatif dan perkembangan moral individu secara rasional dan berarti tanpa acuan pada konsep tentang yang adikodrati/s supranatural-diluar kodrat alamiah (Lorens Bagus, 2000: 295).

Humanisme juga dapat diartikan sebagai cara hidup berdasarkan kemampuan-kemampuan manusia dan sumber-sumber masyarakat dan alam. Seseorang humanis memandang manusia sebagai hasil (produk) dari alam ini, 
dari evolusi dan sejarah manusia dan tidak mengakui akal kosmos (alam) atau tujuan dan kekuatan supernatural. Humanisme mengekpresikan suatu sikap atau kenyakinan yang meminta penerimaan tanggung jawab untuk kehidupan manusia di dunia ini, dengan menekankan sikap hormat yang timbal balik dan mengakui interdependensi manusia (Harold H. Titus, 1984: 308).

Frederick Edword membuat beberapa ringkasan mengenai pengertian humanisme. Dalam hal ini, dia membagi humanisme sebagai berikut:

a. Humanisme Renaisans; sebagai semangat belajar yang mulai berkembang pada akhir abad pertengahan yakni sekitar abad kesebelas dan kedua belas, ditandai dengan bangkitnya karya-karya klasik dan kenyakianan yang diperbaharui atas kemampuan manusia untuk menentukan kebenaran dan kepalsuan bagi diri mereka sendiri. Humanisme Renaissance mempunyai ciri khas yakni; Pertama, adanya minat yang besar dan proyek yang besar untuk melanjutkan dan mengembangkan tradisi retorika dalam dunia Barat. Kedua, berkaitan erat dengan tujuan umum pendidikan humanistik sebagai persiapan atas tugas pelayanan public (Thomas Hidya Tjaya, 2004: 27-29).

b. Humanisme Literer, yakni penyerahan kepada budaya humanitas atau literer.

c. Humanisme budaya, yakni budaya rasional dan empiris, khususnya yang berasal dari Romawi dan Yunani Kuno, dan berevolusi sepanjang sejarah Eropa. Sekarang menjadi bagain yang mendasar dari pendekatan Barat terhadap ilmu pengethuan, teori politik, etika dan hukum.

d. Humanisme Filsufis, yakni pengekspresian cara hidup yang dipusatkan pada minat dan kebutuhan manusia, yang meliputi humanisme kristiani dan humanisme modern.

e. Humanis Kristiani, yakni aliran dalam filsafat yakni sebagai pengancur pemenuhan diri dalam rangka prinsip-prinsip kristiani. Hal ini lebih berorentasi kepercayaan manusia yang sebagin besar merupakan produk pencerahan danbagian dari apa yang membuat humanisme pencerahan.

f. Humanis modern, merupakan sebuah pemikiran filsafat alam dan menolak hal-hal yang bersifat supranatural. Humanisme ini mengandalkan kemampuan akal dan ilmu pengetahuan, demokrasi dan keharuan pada manusia. Humanisme ini mempunyai sifat sekuler sekaligus religi.

g. Humanisme sekuler, merupakan lanjutan dari era pencerahan pada abad XVIII dan kebebasan pemikiran pada abad XIX

h. Humanisme Religius, sebagai humanisme yang mencul dari budaya etis utilitarianisme dan universalisme (Listiyono Santoso, 2003: 36).

Pemahaman atas manusia sebagai individu yang tidak beda dengan sesamanya, adalah sikap humanistis. Berdasarkan konsep tersebut, humanisme merupakan bagian dari kehidupan manusia yang harus dikedepankan untuk kepentingan bersama manusia itu sendiri. Humanisme tidak bisa berkembang tanpa para pemikir memahami makna yang sesungguhnya dari humansime. Dengan memahami humansime secara mendalam, maka para pemikir dalam bidang kajian lain mulai memasukan konsep humanisme dalam segala bidangnya masing-masing.

\section{Landasan Pendidikan Humanis}

Dalam konsep pendidikan humanis ini, bila ditelusuri terdapat tiga aliran pendidikan yang dijadikan pendekatan atau sebagai paradigma/landasan pendidikan nya. Pertama, aliran progresivisme. Aliran progresivisme ini adalah salah satu aliran filsafat pendidikan yang berkembang dengan pesat pada permulaan abad ke-20 dan sangat berpengaruh dalam pembaharuan pendidikan. Progresivisme sebagai teori pendidikan muncul sebagai reaksi yang nyata terhadap pendidikan tradisional, yang menekankan pada metode-metode pengajaran formal, mental belajar, dan literatur-literatur klasik. Karena progresivisme sendiri selalu berhubungan dengan pengertian the liberal road to cultural, yakni liberal bersifat fleksibel (lentur dan tidak kaku), toleran dan bersikap terbuka, serta ingin mengetahui dan menyelidiki demi pengembangan pengalaman (Djumransjah, 2004: 176).

Harus diakui bahwa progresivisme, yang kemudian dikembangkan oleh John Dewey adalah sebuah aliran pendidikan yang sudah sangat mapan, dan keberadaannya telah mempengaruhi sistem pendidikan di belahan dunia (Muis Sad Iman, 2004: viii). Prinsip dasar aliran ini bahwasanya asal dan tujuan proses pendidikan bisa ditemui pada diri anak. Aliran ini mempunyai konsep yang mempercayai manusia sebagai subyek yang memiliki

kemampuan menghadapi dunia dan lingkungan hidupnya, serta kemampuan untuk mengatasi dan memecahkan masalah-masalah yang akan mengancam manusia itu sendiri. Pendidikan dianggap mampu untuk 
merubah dan menyelamatkan manusia demi masa depannya, sebagaimana ungkapan Hegel, "the dynamic, everreadjusting processes of nature and society". Dengan kata lain, alam dan masyarakat bersifat dinamis dalam proses penyesuaian dan perubahan yang tidak pernah berhenti (Djumransjah, 2001: 179).

Kedua, aliran konstruktivisme. Konstruktivisme dikemukakan pertama kali oleh Giambatista dan kemudian diperkenalkan oleh Mark Baldwin serta dikembangkan lebih lanjut oleh Jean Piaget. Dalam teori pendidikan ini, secara ontologis, heterogenitas yang menjadi dasar pandangan tentang realitas, yang membuat paradigma konstruktivisme menjadi dinamis. Disini, individu dipandang sebagai makhluk yang otonom dan mandiri. Dalam hal ini, belajar menjadi bersifat demokratis sesuai dengan kebutuhan minat dan diferensiasi individu. Disini anak diperlakukan sesuai dengan kemampuan bakat dan minat sehingga kegiatan belajar itu dirasakan sebagai sesuatu yang menyenangkan, karena anak akan berkembang sesuai dengan gerak dinamikanya masing-masing (Ahmad Samawi, 2000: 5-8).

Ketiga, aliran eksistensialisme. Eksistensialisme pada hakikatnya merupakan aliran filsafat yang bertujuan mengembalikan keberadaan umat manusia sesuai dengan keadaan hidup asasi yang dimiliki dan dihadapinya. Aliran ini dikembangkan oleh Kierkegaard, dan Sartre. Eksistensialisme lahir sebagai reaksi terhadap dua aliran yang memiliki pandangan ekstrem, yaitu materialisme, yang memandang manusia sebagai obyek dan materi sebagai keseluruhan manusia, dan idealisme, yang dikembangkan Hegel, yang memandang manusia sebagai subyek kesadaran dengan terlalu meremehkan eksistensi yang kongkret manusia, mengutamakan idea yang sifatnya umum, serta menjunjung aspek kesadaran yang sangat berlebihan sehingga seluruh manusia tergantung dari berpikir (Firdaus M. Yunus, 2005: 32-33).

Dari ketiga aliran pendidikan inilah konsep pendidikan humanis melahirkan pola filsafat pendidikan yang dianggap membebaskan sebagai jalan untuk menanggulangi dehumanisasi dalam pendidikan . Hal tersebut diperkuat oleh Mahmud Rajabi (2006: 34-35), bahwa salah satu dasar pemikiran humanisme adalah rasionalisme, yaitu suatu keyakinan pada kemandirian akal manusia dalam memahami dirinya, realitas, kebahagiaan hakikinya, serta jalan untuk mencapainya, dan liberalisme yang meyakini bahwa manusia lahir atas dasar kebebasan atau harus selalu bebas dari segala keterikatan kecuali oleh sesuatu yang dia tentukan untuk dirinya sendiri.

\section{Tujuan Pendidikan Humanis}

Sebenarnya dengan mengetahui gambaran manusia yang mau dicapai, sudah menjadi nampak apa sebenarnya yang menjadi tujuan utama pendidikan humanis. Akan tetapi berhubung ide tentang manusia merupakan deskripsi, kiranya belum cukup memadai untuk manarik begitu saja dari dalamnya tentang apa yang menjadi tujuan pendidikan humanis.

Menurut Paulo Freire (1972: 190), tujuan pendidikan yang humanis adalah untuk mencari ilmu pengetahuan guna memenuhi hasrat dan keinginan peserta didik dan Pendidik dengan kesadaran untuk menciptakan ilmu pengetahuan baru. Kesadaran manusia dibentuk melalui pendidikan dan aksi-aksi budaya yang membebaskan. Klaim pendidikan sebagai sebuah praktek pembebasan yang ditujukan untuk mengkaji ilmu baru, hal ini tidak akan tercapai jika perlakuan terhadap kesadaran manusia sama seperti perlakuan pendidikan yang dominatif. Freire menegaskan, Pendidik yang humanis harus tepat dalam memahami hubungan dalam kesadaran manusia antara manusia dan dunia. Dengan demikian Freire menekankan akan tujuan pendidikan untuk membentuk kesadaran manusia guna menciptakan ilmu pengetahuan baru (Imam Muslimin, 2004: 122).

Ki Hajar Dewantara (1962: 14-15), menyatakan bahwa tujuan pendidikan adalah supaya dapat memajukan kesempurnaan hidup peserta didik, yaitu selaras dengan kodratnya, serasi dengan adat-istiadat, dinamis, memperhatikan sejarah bangsa dan membuka diri pada pergaulan dengan kebudayaan lain.

Sedangkan Hamalik (2001:45) merinci tujuan pendidikan humanis sebagai berikut;

a) Mengembangkan pengalaman dan seluruh potensi anak didik melalui pendidikan yang sesuai dengan kebutuhannya.

b) Mengembangkan aktualisasi diri dan kepribadian anak didik

c) Mengembangkan keterampilan-ketreampilan dasar seperti aspek akademik, pribadi, hubungan antar insani, komunikasi dan ekonomi yang dibutuhkan dalam kehidupan bersama.

d) Melibatkan anak didik dalam kegiatan pendidikan . 
e) Menghayati pentingnya perasaan manusiawi dan menggunakan nilai-nilai dan persepsi personal sebagai faktorfaktor yang terintegrasi dalam proses pendidikan .

f) Mengembangkan suasana belajar yang kondusif dengan cara menciptakan suasana belajar yang memberikan tantangan, menumbuhkan pemahaman, bersifat mendukung serta bebas dari kecemasan.

g) Mengembangakan rasa hormat pada orang lain dan keterampilan menyelesaikan konflik dalam kehidupan bermasyarakat.

Dapat ditarik suatu kongklusi bahwa tujuan pendidikan humanis adalah proses pembebasan dan pemanusiaan. Sebuah proses penyadaran yang terarah sekaligus memproduksi suatu pembebasan yang dinamis sehingga tercipta iklim kemanusiaan yang lebih utuh (conscientizacao). Ada tiga kesadaran yang secara integral saling berhubungan, yaitu kesadaran magic, naï, dan kritis. Tahap kesadaran kritis merupakan tujuan prioritas pendidikan humanis sehingga manusia secara sadar mampu memahami realitas sekitarnya dengan kritis. Kekritisan akan melahirkan sebuah tindakan kreativitas yang progresif-inovatif dalam lingkup sosio-kultur kehidupannya. Karena konsepsi kesadaran kritis didasarkan terhadap konsepsi hubungan dialektis antara dunia dan kesadaran manusia itu sendiri sebagai proses menuju pembebasan.

\section{Implementasi Pendidikan Humanis dalam Proses Belajar Mengajar}

\section{a. Karakteristik Belajar}

Sejak awal keberadaannya, manusia telah melakukan aktivitas belajar, karena belajar adalah salah satu kebutuhan manusia. Pada umumnya belajar diartikan sebagai aktivitas menghimpun pengetahuan dari orang yang dianggap lebih tahu kepada orang yang kurang tahu. Freire menyebut model belajar ini dalam sistem pendidikan bank yang sangat ditentangnya. Freire sendiri memandang belajar sebagai proses pencapaian kesadaran kritis oleh peserta didik. Filosof sekaligus psikolog humanistik, Carl Rogers, mengatakan belajar sebagai tindakan membiarkan kebebasan peserta didik untuk berekspresi sehingga tak ada unsur paksaan di dalamnya. Proses belajar seperti ini bukanlah proses mencetak seseorang menjadi orang lain, melainkan tindakan membiarkan dan memupuk seseorang menjadi dirinya sendiri (Siti Murtiningsih, 2004: 100).

Sebagaimana dikemukakan sebelumnya, salah satu fungsi pendidik (Pendidik ) dalam pendidikan humanis adalah sebagai fasilitator. Pendidik yang mampu memfasilitasi pertumbuhan dan perkembangan peserta didik sangat diperlukan agar peserta didik peka terhadap berbagai aspek belajar. Pendidik seperti itu cenderung mampu membantu peserta didiknya belajar secara mandiri, mendorongnya untuk menyelidiki sendiri, menggunakan berbagai sumber serta menghayati kegembiraan ataupun kegelisahan dalam belajar.

Secara konvensional, Pendidik (pendidik ) setidaknya harus memiliki tiga kualifikasi dasar, yaitu menguasai materi, antusiasme, dan penuh kasih sayang (loving) dalam mengajar dan mendidik (Abdurrahman Mas'ud, 2002:194). Meskipun loving merupakan kualifikasi yang paling akhir, sesungguhnya harus ditempatkan pada urutan pertama. Pendidik harus mengajar dengan berlandaskan cinta kepada sesama umat manusia tanpa memandang status sosial ekonomi, agama, kebangsaan, dan lain sebagainya. Misi utama Pendidik adalah enlightening (mencerdaskan bangsa), mempersiapkan anak didik sebagai individu yang bertanggungjawab dan mandiri. Proses pencerdasan harus berangkat dari pandangan filosofi Pendidik bahwa anak didik adalah individu yang memiliki beberapa kemampuan dan keterampilan.

Dalam pengajaran, pendidik harus mempertimbangkan kebutuhan tersebut, karena pada dasarnya peserta didik memiliki keinginan alami untuk berkembang dan belajar. Pendidik tidak berhak membunuh keinginan (character assasination) tersebut dengan memaksa mereka mempelajari sesuatu yang belum siap atau ingin mereka pelajari. Fungsi pendidik terbatas pada humanistic facilitator dalam membantu peserta didik untuk memperoleh kebutuhan mereka. Pendek kata, pendekatan humanistik (humanistic approach) dalam pendidikan menekankan kemungkinan untuk perkembangan yang positif. Masing-masing peserta didik memiliki potensi yang dapat dikembangkan, dan fungsi pendidik adalah membantunya dalam mengembangkan potensi tersebut.

Proses belajar humanis berusaha mengajar peserta didik tentang proses atau keterampilan yang mereka butuhkan, atau yang akan mengarahkan kehidupan mereka yang berkaitan erat dengan identitas dan kelebihannya.

Latihan hubungan peserta didik (seperti latihan komunikasi, orang tua yang efektif, dan pertemuan kelompok) merupakan contoh lain yang mengajarkan proses mendengar, memberi dan menerima umpan balik, 
dan menyelesaikan konflik atau problem solving. Motivasi berprestasi merupakan pendekatan proses lainnya yang menekankan pembentukan tujuan, pengambilan resiko, dan perencanaan prestasi yang akan dicapai.

Kata kunci untuk pengembangan belajar humanis adalah sejauh mana Pendidik mampu memahami, mendekati, dan mengembangkan Peserta didik sebagai individu yang memiliki potensi yang sama, kaitannya dengan potensi kekhalifahan dan potensi-potensi unik sebagai makhluk Tuhan yang didesain sebagai ahsanu taqwim. Di sini kemudian dibutuhkan sebuah pendekatan atau cara sebagai proses membentuk karakteristik belajar yang humanis, yaitu proses liberating berarti Pendidik membebaskan Peserta didik dari belenggubelenggu yang berhubungan dengan kultur, irrasionalitas tradisi dan ideologi, juga belenggu historical burden. Proses liberating dilanjutkan dengan proses educating, yaitu menuju kesempurnaan Peserta didik dengan posisi Pendidik sebagai mitra kesempurnaan, fasilitator, dan motivator. Setelah dua proses berjalan secara proporsional, civilizing betul-betul akan menempatkan murid pada posisi fitrahnya sebagai khalifatullah fil ardl. Tiga proses ini memang harus didukung oleh semua aspek pendidikan yang ada, tidak hanya oleh Pendidik sebagai single fighter (Abdurrahman Mas'ud, 2002: 201).

Dapat disimpulkan bahwa proses belajar dalam pendidikan humanis mempunyai beberapa karakter yang harus diperhatikan supaya proses pembelajaran berjalan sesuai harapan, yaitu berangkat dari suatu asumsi positif bahwa peserta didik mempunyai akal dan kecerdasan yang sama, memberi ruang kebebasan bagi peserta didik untuk beraktualisasi sendiri (berpikir kritis, berkreasi, berinovasi, dll), pendidik harus mempertimbangkan segi kebutuhan peserta didik, mengajar tentang proses atau keterampilan yang dibutuhkan, berinteraksi dengan penuh cinta dan kasih sayang.

\section{b. Interaksi Pendidik -Peserta didik dalam Proses Belajar Mengajar}

Interaksi pendidik -peserta didik merupakan komponen penting dalam pembelajaran. Pendidik yang berprilaku positif cenderung memiliki peserta didik yang berprestasi tinggi dan memiliki keterampilan positif dalam mengerjakan tugas. Karena pendidik yang mampu menciptakan lingkungan belajar yang menyenangkan dan melibatkan peserta didik dalam pembelajaran lebih menguntungkan dalam pencapaian tujuan pembelajaran. Oleh karena itu, interaksi yang baik pendidik -peserta didik memberi kontribusi terhadap dinamika pencapaian tujuan pembelajaran. Dalam hubungan tersebut, terhimpun kemampuan pendidik dalam melakukan penerimaan (acceptance), memahami perasaan peserta didik, menciptakan suasana hangat, menumbuhkan sikap jujur, empati, dan bentuk interaksi sosial positif lainnya. Untuk itulah, perlu adanya pengenalan karakteristik peserta didiknya dan meningkatkan interaksi sosial dengannya.

Keberadaan pendidik dengan segala aspek kemampuan dan kepribadian yang dimilikinya-termasuk faktor budaya-mempengaruhi persepsi sosial peserta didik tentang pendidik (Pendidik nya), teman sekelas, dan dirinya sendiri. Sedangkan peserta didik dengan segala kemampuan dan karakteristik yang dimilikinya mempengaruhi cara mengajar Pendidik . Dengan kata lain, prilaku Pendidik mempengaruhi prilaku peserta didik, dan sebaliknya prilaku peserta didik mempengaruhi prilaku Pendidik nya dalam pembelajaran. Kualitas hubungan Pendidik -peserta didik berpengaruh kuat terhadap prilaku dan prestasi peserta didik. Hubungan peserta didik yang positif dengan Pendidik dapat menumbuhkan harga diri (self esteem) dan mengembangkan konsep diri Peserta didik yang positif.

Pendidikan humanis, dalam proses belajar mengajar, diarahkan untuk mengembangkan keterampilan, sikap dan pengetahuan anak melalui metode belajar partisipatoris dan kooperatif, serta suasana saling toleransi, peduli, dan saling menghargai. Melalui aktivitas dialog dan eksplorasi, pendidik dan peserta didik melakukan petualangan belajar interaktif (Abd. Rahman Assegaf, 2004: 94). Untuk itu perlu penciptaan suasana yang kondusif dalam meningkatkan minat dan motivasi belajar anak. Karena pendidikan humanis menempatkan kesetaraan sebagai prinsip utama dalam interaksi belajar-mengajar antara Pendidik dan Peserta didik; ia mementingkan interaksi kesalingan (mutual interaction) sebagai bingkai hubungan sosial di dalam dan di luar kelas (Zakiyuddin Baidhawy, 2005:104).

Bobbi DePorter (2003: 19-39) menyarankan terpenuhinya enam suasana agar dapat membangkitkan minat, motivasi, dan keriangan peserta didik dalam mengikuti proses belajar. Pertama, menumbuhkan niat belajar. Keyakinan seseorang mengenai kemampuan dirinya amat berpengaruh pada kemampuan itu sendiri. Dalam proses belajar mengajar, baik Pendidik maupun Peserta didik hendaknya dapat membangkitkan niat tersebut dari dalam dirinya sendiri. 
Kedua, menjalin rasa simpati dan saling pengertian untuk menumbuhkan kepedulian sosial, sikap toleransi dan saling menghargai di antara Peserta didik. Ada beberapa langkah yang bisa ditempuh, antara lain: memperlakukan Peserta didik sebagai manusia sederajat; mengetahui apa yang disukai Peserta didik, cara berpikir mereka, dan perasaan mereka mengenai hal-hal yang terjadi dalam kehidupan mereka; membayangkan apa yang Peserta didik katakan; mengetahui hal yang menghambat para Peserta didik dalam memperoleh hal yang benar-benar mereka inginkan; berbicara dengan jujur kepada para Peserta didik dengan cara yang membuat mereka mendengarkan dengan jelas dan halus; dan melakukan kegiatan yang menyenangkan bersama para Peserta didik.

Ketiga, menciptakan suasana riang. Kegembiraan membuat Peserta didik lebih mudah untuk belajar dan bahkan dapat mengubah sikap negatif. Belajar dalam iklim yang menyenangkan, tanpa ada paksaan dan tekanan, akan menimbulkan kesadaran untuk menemukan sendiri jawaban persoalan yang dihadapi. Sebaliknya suasana tegang dan tertekan mengakibatkan Peserta didik belajar dengan terpaksa. Hal terpenting dari langkah ini adalah tetap menjaga suasana riang agar tidak berubah menjadi senda gurau.

Keempat, mengambil resiko. Keberanian mengambil resiko yang menantang terletak keasyikan tersendiri dalam belajar. Hal itu hendaknya diwujudkan dalam suasana belajar di ruang kelas: tidak mudah menyerah dalam menyelesaikan persoalan, terus berpikir untuk memecahkan masalah tersebut. Belajar dengan tantangan bisa mengurangi kejenuhan dan rasa kebosanan.

Kelima, menciptakan rasa saling memiliki. Sebab, rasa saling memiliki membentuk kebersamaan, kesatuan, kesepakatan dan dukungan dalam belajar. Rasa saling memiliki juga akan mempercepat proses mengajar dan meningkatkan rasa tanggung jawab peserta didik. Pendidikan humanis amat mementingkan kebersamaan, kesatuan dan kesepakatan bersama untuk saling menghargai perbedaan dan menyelesaikan persoalan.

Dan keenam, menunjukkan teladan yang baik (uswah hasanah). Prilaku nyata akan lebih berarti daripada seribu kata (lisan al-hal abyan min lisana al-maqal). Hal yang diperbuat oleh Pendidik akan menjadi cermin bagi para Peserta didik. Untuk itu, sebaiknya mendahulukan bukti-bukti berupa sikap, sikap kasih sayang, empati, toleran, disiplin dan lain sebagainya, sebelum mengajarkan dengan kata kepada orang. Jadi, memberi teladan merupakan salah satu cara ampuh untuk membangun hubungan dan memahami orang lain, karena keteladanan membangun hubungan, memperbaiki kredibilitas, dan meningkatkan pengaruh (Bobbi DePorter,2003: 18).

Perlu ditegaskan di sini, bahwa kualitas hubungan Pendidik -Peserta didik sangat berpengaruh kuat dalam membentuk prilaku dan prestasi para Peserta didik. Untuk itu, para Pendidik dituntut mengembangkan Peserta didik sesuai dengan potensi atau kemampuan yang dimilikinya dengan berlandaskan prinsip kemanusiaan

Beberapa sikap yang harus dilaksanakan-terutama oleh Pendidik selaku penanggungjawab pelaksana pembelajaran-di dalam proses belajar mengajar antara lain:

a. Memunculkan Rasa Empati Terhadap Peserta didik

Pendidik harus menerima Peserta didiknya menurut pribadi masing-masing dan dapat menghargai sifat-sifat mereka meskipun menyimpang dari yang umumnya dianggap baik. Sikap menerima dan menghargai tersebut pada dasarnya sama dengan keyakinan akan kemampuan Peserta didik untuk belajar dan berkembang. Di samping menerima Peserta didik sebagaimana adanya, Pendidik dituntut mempercayai Peserta didik dan ikut merasakan yang dipikirkan dan dirasakan Peserta didik. Pendidik hendaknya menghargai perasaan, pandangan dan diri Peserta didik, yaitu orang yang patut dipercayai. Hubungan Pendidik -Peserta didik merupakan hubungan yang hangat, tidak suka menguasai, tidak mengancam, dan memuaskan. Untuk itu Pendidik seharusnya berprilaku sebagai berikut. Pertama, memberikan kebebasan kepada Peserta didik untuk berpartisipasi dalam pemilihan kegiatan belajar. Peserta didik memiliki kemungkinan untuk memilih bahan, projek, dan ikut dalam perancangan dan implementasi pengajaran. Pendidik bertindak sebagai fasilitator daripada sebagai ahli. Kegiatan kelas dilakukan bersama Peserta didik (learning together), dan masukan serta ide-ide Peserta didik dihargai dan dilaksanakan jika ide tersebut baik untuk kemajuan pendidikan .

Kedua, Pendidik menaruh minat, memperhatikan, dan ikut bertanggungjawab terhadap Peserta didiknya. Hal ini dapat ditunjukkan dengan sikap ramah, suara yang nyaman, anggukan, senyum, hubungan perseorangan, menanyakan perasaan dan pikirannya tanpa harus ada jarak antara keduanya. Pendidik 
dengan rasa kerendahan hati mau mendengarkan pertanyaan, pernyataan, keluhan, serta memperhatikan pendapatnya.

Ketiga, Pendidik harus menunjukkan sikap empatinya, menghayati apa yang dipikirkan dan dirasakan Peserta didiknya. Pendidik hendaknya mengurai kembali apa yang diungkapkan Peserta didiknya, menjadi pendengar yang baik dengan memperhatikan Peserta didik yang berbicara dan tidak memotong pembicaraannya. Setiap individu akan merasa senang apabila mendapat perhatian dan cenderung akan menjadi lebih respek dan komunikatif.

b. Mengakui Konsep Diri Peserta didik

Konsep diri (self-concept) merupakan gambaran individu tentang dirinya sendiri. Konsep ini cenderung dapat dibimbing, mengendalikan, dan mengatur tindakan seseorang dalam upaya menyesuaikan diri dengan lingkungannya. Peserta didik yang menganggap dirinya mampu dan cerdas, mungkin akan senang bekerjasama, berpartisipasi dalam kegiatan sekolah dan mau membantu orang lain. Sebaliknya, Peserta didik yang memiliki konsep diri negatif tidak memiliki kegembiraan hidup seperti Peserta didik yang memiliki konsep diri yang positif.

Konsep diri tumbuh setelah individu membuat perbandingan dirinya dengan orang lain. Untuk itu, Pendidik hendaknya sering memberikan penguatan (reinforcement) dan menunjukkan kepada Peserta didik untuk mau bergaul secara baik. Peserta didik yang tidak senang bergaul harus didekati agar tidak terbentuk konsep diri yang negatif. Peserta didik yang mempunyai sikap seperti itu harus diberi motivasi agar memperoleh perasaan yang mampu membangkitkan rasa percaya dirinya.

Konsep diri yang positif pada Peserta didik dapat dibentuk dengan beberapa cara, yaitu Pertama, membuat kontrak kegiatan bersama Peserta didik. Cara ini dapat membantu Peserta didik untuk memilih kegiatan yang sesuai dengan tingkat kemampuannya. Kontrak kegiatan tidak memaksa Peserta didik untuk mencapai tingkat yang sama. Kedua, memberikan umpan balik (feedback) yang positif. Umpan balik dapat berupa nilai, komentar, saran, atau bimbingan. Ketiga, tidak menetapkan tujuan yang terlalu muluk untuk dapat dicapai Peserta didik, harus disesuaikan kemampuan masing-masing Peserta didik. Persyaratan yang bervariasi untuk setiap Peserta didik dengan memperhatikan kekuatan dan kelemahannya.

c. Menumbuhkan Sikap Toleransi

Sikap toleransi memang amat mudah diucapkan tetapi sulit diaplikasikan dalam tingkah keseharian. Dan bahasa Jawa, toleransi disebut tepa selira, yaitu sikap menjaga perasaan orang lain agar ia tidak tersinggung (Abd. Rahman Assegaf, 2004: 107). Toleransi mengandung sikap agree in disagreement, mendiamkan atau membiarkan suatu perbuatan, sikap atau pendapat orang lain yang berbeda dengan diri sendiri, meski terdapat pebedaan secara diametral sekalipun. Menghargai perbedaan berarti siap untuk menerima kehadiran orang lain di tengah kehidupan kita secara kolektif, learning to live together.

Dalam proses belajar mengajar, sikap toleransi dapat ditumbuhkan melalui berbagai metode pembelajaran. Seorang Pendidik di tengah-tengah mengajarnya, memberi waktu luang untuk tukar pendapat, diskusi, atau tanya jawab untuk bertanya, membahas, usul, mengkritik atau bahkan berani menolak pendapatnya mengenai suatu masalah yang dilakukan secara rasional dan argumentatif dengan menghargai perbedaan pendapat di antara peserta didik.

d. Pendidik sebagai Fasilitor

Fungsi Pendidik sebagai fasilitator diharapkan sosok Pendidik yang selalu mendukung Peserta didiknya dalam belajar. Pendidik memberi kesempatan kepada Peserta didiknya untuk memilih, baik dalam bentuk kegiatan maupun dalam isi bahan pelajaran, dengan konsekuensi Peserta didik harus mampu bertanggungjawab atas segala sesuatu yang menjadi pilihannya.

Sebagai fasilitator, Pendidik harus membantu Peserta didik dalam kegiatan inkuirinya. Pendidik sebaiknya membiarkan Peserta didik menggunakan berbagai sumber untuk mencari sendiri apa yang diinginkannya dan untuk menemukan makna dari yang dipelajarinya. Membiarkan dalam artian tidak secara mutlak, tetapi dalam proses pengembangannya nanti, Pendidik diharuskan tetap selalu memonitor dan 
membimbing segala aktivitas Peserta didik. Serta tidak bosan-bosan meminta Peserta didik untuk menelaah segala yang bermanfaat dari materi yang sedang dipelajarinya, baik untuk dirinya maupun masyarakat.

e. Pendidik Menciptakan Suasana Pedagogi-Dialogis

Perlu diingat bahwa salah satu prinsip belajar dalam pendidikan humanis adalah learning together dan learning to live together. Peserta didik akan lebih mudah belajar apabila pengajar berpartisipasi sebagai teman yang lebih tua dalam pengalaman belajar yang sedang dia alami. Pendidik perlu menyadari bahwa ia tidak menguasai seluruh bahan. Dengan demikian, hubungan Pendidik -Peserta didik tidak lagi berupa hubungan antara seorang ahli dengan Peserta didik, tetapi lebih ditekankan kepada hubungan yang didasarkan atas dua pribadi. Dalam pengajaran, Pendidik mengurangi ceramahnya, namun meningkatkan interaksi dengan Peserta didiknya.

Prinsip seperti ini, akan memudahkan bagi Peserta didik untuk membentuk kelas dialogis dengan Pendidik atau antar Peserta didik tanpa adanya perasaan sungkan. Karena rasa sungkanisme yang tinggi sangat tidak menguntungkan dalam dunia pendidikan -sebagai wadah untuk berproses-karena akan membunuh kritisisme berpikir Peserta didik. Kritisisme akan muncul ketika antara Pendidik -sebagai orang yang mempunyai pengalaman lebih dulu-dengan Peserta didik yang baru berproses tidak lagi ada jarak yang terlalu jauh. Seperti yang dikatakan Ira Shor (1987: 159), perlunya pedagogi yang disituasikan (dialogis). Dalam pedagogi yang distuasikan, seorang Pendidik bersama Peserta didik menggali tema-tema yang menurut persepsi mereka sangat problematis. Mensituasikan pedagogi kritis pada problema yang bertema subjektif yang belum dianalisis oleh Peserta didik, akan mendorong motivasi intrinsik terhadap bahan ajar yang menjadi perhatian utama peserta didik. Selain itu juga memberikan momen pelepasan atas pengalaman yang belum pernah direfleksikan sebelumnya.

f. Mengkombinasikan Perasaan dengan Bahan Pengajaran

Konsep humanistik sangat menekankan kasih sayang dalam pengajaran sebagaimana prinsip dalam Islam, bahwa segala aktivitas baik pendidikan untuk mencerdaskan bangsa dan meningkatkan sumber daya manusia, dilaksanakan dalam rangka mewujudkan kehidupan yang penuh kasih sayang (QS. 21: 107), tetapi tidak ada kasih sayang (emosi) tanpa kognisi dan tidak ada kognisi tanpa emosi. Mengkombinasikan bahan dan perasaan ini terkadang disebut ajaran tingkat ketiga. Ajaran tingkat kesatu adalah fakta, tingkat kedua adalah konsep, dan ajaran tingkat ketiga adalah nilai.

Relasi antara fakta, konsep, dan nilai dapat digambarkan dengan suatu piramida. Alas pertama yang lebar menggambarkan fakta; konsep merepresentasikan pemahaman dan perumusan yang diturunkan dari fakta; sedang puncak piramida menggambarkan nilai, yaitu suatu rujukan dan keyakinan dalam menentukan pilihan (Rohmat Mulyana, 2004: 8-11).

Puncak piramida menggambarkan bahwa keputusan yang diambil dalam hidup merupakan keputusan yang didasarkan atas fakta dan konsep. Pengajaran yang bermakna hendaknya mencakup ketiga tingkat tersebut. Pembahasan nilai yang tergabung dalam konsep seharusnya merupakan suatu kesatuan dalam pengalaman belajar di kelas. Oleh karena itu, Pendidik dan Peserta didik secara bersama-sama perlu menguji dan menjelajah nilai-nilai yang mendasari bahan pengajaran.

g. Adanya Transparansi Pendidik -Peserta didik

Adanya keterbukaan Pendidik dimaksudkan agar Pendidik tidak menutupi kepribadian yang sesungguhnya. Ia harus secara jujur menampakkan perasaan yang sebenarnya, yaitu bahwa Pendidik dapat merasa benci atau suka, senang dan sedih, marah, jengkel, atau gembira. Keterbukaan Pendidik tersebut diharapkan dapat mendorong Peserta didik mengungkapkan emosi dan perasaannya, sehingga membantu Pendidik dan Peserta didik memahami karakteristik masing-masing.

Prinsip dari pola-pola interaktif Pendidik -Peserta didik sebagaimana di atas berorientasi terhadap adanya kebebasan yang diberikan Pendidik kepada Peserta didik untuk berkreativitas secara kritis dan inovatif, karena tidak akan ada kreativitas tanpa kebebasan. Kreativitas sebagai proses interaktif antara individu dengan lingkungannya. Seseorang yang kreatif dapat terlihat dari kemampuannya mengatasi 
masalah (problem sensitivity), mampu menciptakan ide alternatif untuk memecahkan masalah (idea fluency), mampu memindahkan ide dari satu pola piker ke pola piker yang lain (idea flexibility). Orang yang kreatif pun dapat dilihat dari kemampuannya untuk menciptakan ide yang asli (idea originality). Seluruh kemampuan pengembangan ide dan sensivitas terhadap persoalan yang merupakan cirri kreatif tersebut tidak akan dapat terbentuk bilamana dalam diri seseorang terjadi tekanan dan pembatasan atas kebebasannya.

Pola hubungan interaktif Pendidik -Peserta didik menerapkan sistem andragogi. Sistem ini menuntut memang keaktifan Peserta didik untuk berbuat (learning by doing). Di sini Peserta didik diberi umpan dan kail, kemudian dibimbing untuk mencari ikan sendiri. Peran Pendidik dalam proses belajar mengajar yang andragogis adalah sebagai mediator, fasilitor atau pembina. Dalam proses pembelajaran yang seperti inilah, akan terjadi interaksi yang intens antara Pendidik -Peserta didik, Peserta didik-Peserta didik, bahkan Pendidik -Pendidik , sehingga pola komunikasinya berbentuk multi-ways traffic communication (pola komunikasi multi-arah). Pola ini anti-tesis dari pola komunikasi satu arah (one ways traffic communication) yang masih banyak digunakan dalam sistem pendidikan di Indonesia selama ini (Abd. Rahman Assegaf, 2004: 141).

Dalam pola komunikasi multi-arah (multi-ways traffic communication) melibatkan keaktifan dan kreativitas semua pihak, antara sesama peserta didik, pendidik , bahkan antar sesama Pendidik pun terjadi interaksi yang intens. Materi dan metode pengajarannya tidak lagi didominasi oleh Pendidik semata, melainkan juga melibatkan keikutsertaan para Peserta didik (student-centered, student active learning). Akibatnya, semua pihak dapat berkomunikasi dan saling memberi masukan. Pola ini jelas lebih bebas dan demokratis sebagaimana prinsip dalam pendidikan humanis.

Dapat disimpulkan, bahwa proses belajar mengajar, pendidik tetap memegang peran penting untuk menciptakan suasana belajar yang kondusif. Demi terciptanya suasana yang demikian itu, pendidik harus menjadi qudwah atau teladan baik di dalam dan di luar kelas, terlebih disaat berinteraksi secara langsung di kelas. Karena kualitas hubungan pendidik -peserta didik sangat berpengaruh kuat dalam membentuk prilaku dan prestasi para peserta didik. Untuk itu, pendidik harus mampu memunculkan rasa empati terhadap peserta didiknya, mengakui konsep diri Peserta didik baik yang positif maupun yang negatif untuk selanjutnya mampu memberi motivasi, menumbuhkan sikap toleransi, memposisikan dirinya sebagai fasilitator, menciptakan suasana belajar dialogis, mampu mengkombinasikan antara perasaan (keinginan peserta didik) dengan bahan pengajaran, dan Pendidik dengan segala kerendahan hati dituntut transparan atas segala kekurangan. Jadi, pola interaksi pendidik -peserta didik menggunakan pola ways traffic communication (pola komunikasi multi-ara

\section{SIMPULAN}

Konsep pendidikan humanis merupakan sebuah proses penyadaran dan peningkatan terhadap harkat kemanusiaan serta potensi yang dimiliki secara terarah sekaligus memproduksi suatu pembebasan yang dinamis sehingga tercipta iklim pendidikan yang kritis-progresif-inovatif secara utuh (conscientizacao). dengan mengedepankan pola pendekatan dialogis-humanis antara pendidik -peserta didik dan peserta didik dengan lingkungannya (problem possing education). Suatu proses di mana manusia mendapatkan kesadaran tentang realitas kultural yang melingkupi hidupnya dan akan kemampuannya untuk merubah realitas.

Proses penyadaran yang mengarah sekaligus memproduksi suatu konsep pembebasan yang dinamis agar tercipta iklim kemanusiaan yang lebih utuh. Pendidik dan peserta didik ditempatkan dalam posisi belajar bersama (learning together), keduanya berinteraksi dalam memberikan informasi pengetahuan secara horizontal tanpa adanya perendahan martabat salah satunya. Karenanya, seorang pendidi kharus menjadi fasilitator dan partner belajar yang baik dalam proses pendidikan guna tercapainya sebuah kesadaran diri peserta didik sebagai manusia yang multipotensi.

Konsep pendidikan humanis harus praksis dalam proses pendidikan. Jika tidak maka percuma sebuah konsep dibuat. Dalam implementasinya, seorang pendidik harus menjadi qudwah atau teladan yang baik, dengan mengedepankan cinta dan kasih sayang dalam proses mengajar. Pendidik harus mampu memunculkan rasa empati, 
mampu memberi motivasi, menumbuhkan sikap toleransi, memposisikan sebagai teman belajar, menciptakan suasana belajar dialogis, mampu mengkombinasikan antara perasaan (keinginan peserta didik) dengan bahan pengajaran, dan Pendidik dengan segala kerendahan hati dituntut transparan atas segala kekurangan. Sehingga tercipta pola komunikasi multi-arah (ways traffic communication) yang baik antara pendidik dan peserta didik.

\section{DAFTAR RUJUKAN}

Abdurrahman Mas'ud, 2002, Menggagas Format Pendidikan Nondikotomik: Humanisme Religius sebagai Paradigma Pendidikan Islam, Yogyakarta: Gama Media.

Ancok, Djamaluddin, 1998, Peran PerPendidikan Tinggi Dalam Menyiapkan Manusia di Milenium Ketiga, Yogyakarta: UII.

Assegaf Abd. Rahman, 2004, Pendidikan Tanpa Kekerasan, Tipologi Kondisi, Kasus dan Konsep, Yogyakarta: Tiara Wacana

Bagus Lorens, 1996, Kamus Filsafat, Jakarta: PT. Gramedia Pustaka Utama

Budayawan, Wawan, 2018, Dehumanisasi Pendidikan . http://www.bali-travelnews.com.

Danim, Sudarman, 2003, Agenda Pembaharuan Sistem Pendidikan, Yogyakarta, Pustaka Pelajar.

Dawam, Ainurrofiq, 2003, Emoh Sekolah; Menolak "Komersalisasi Pendidikan " dan Kanibalisasi Intelektual", Munuju Pendidikan Multikultural, Yogyakarta, Inspeal Ahimsakarya Press.

DePorter, Bobbi, dkk, 2003, Quantum Teaching: Mempraktikkan Quantum Learning di Ruang-ruang Kelas, Bandung: Kaifa,

Freire, Paulo, 1972. Pendidikan Kaum Tertindas, terj. Tim Redaksi Asosiasi Pemandu Latihan, 1991. Yogyakarta: LP3ES

Handoko, Martin, 1992, dalam Paulus Mujiran, Ketika Dehumanisasi Pendidikan Menjadi Kendala, (http://bruderfic.or.id/, 16 April 2018 )

Harian Pontianak Pos. Kekerasan Di Sekolah "Puncak Gunung Es" Problem Pendidikan . Berita (Pontianak, 14 April, 2007)

Ibrahim, Sulaeman, 2000. Pendidikan Sebagai Imperialisme dalam Merombak Pola Pikir Intelektualisme Muslim, Yogyakarta: Pustaka Pelajar.

Iman, Muis Sad, 2004, Pendidikan Partisipatif, Menimbang Konsep Fitrah dan

Indar, Djumberansjah, 1994, Filsafat Pendidikan, Surabaya: PT. Karya Abditama

Ma'arif, A. Syafi'i, 1991, Pendidikan Islam di Indonesia antara Cita dan Fakta, Yogyakarta: PT. Tiara Wacana.

Mulyana, Rohmat, 2004, Mengartikulasikan Pendidikan Nilai, Bandung: Alfabeta.

Murtiningsih, Siti, 2004, Pendidikan Alat Perlawanan, Teori Pendidikan Radikal Paulo Freire, Yogyakarta: Resist Book

Muslimin, Imam , 2004, Pendidikan dan Humanisme, Jurnal Fakultas Tarbiyah El-Hikmah: UIN Malang, Volume III-Edisi Agustus

Rajabi Mahmud, 2006, Horison Manusia, Jakarta: al-Huda

Samawi, Ahmad, 2000, Perspektif Filsafat tentang Dialektika Paradigmatik dalam Pendidikan, Malang, FIP IKIP Malang.

Suyanto dan Djihad Hisyam, 2000, Refleksi dan Reformasi Pendidikan di Indonesia Memasuki Milenium III, Yogyakarta: Adicita Karya Nusa.

Tilaar, H.A.R., 1999, Pendidikan, Kebudayaan, dan Masyarakat Madani Indonesia, Strategi Reformasi Pendidikan Nasional, Bandung, Remaja Rosdakarya Offset.

2005, Manifesto Pendidikan Nasional, Tinjauan dari Perspektif Postmodernisme dan Studi Kultural, Jakarta: Penerbit Buku Kompas..

Titus, Harold H. dkk., 1984, Persoalan-Persoalan Filsafat, terj. M. Rasyidi, Jakarta: Bulan Bintang,.

Tjaya, Thomas Hidya, 2004, Humanisme dan Skolatisisme; Sebuah debat, Yogyakarta, Kanisius,.

Yunus, Firdaus M, 2005, Pendidikan Berbasis Realitas Sosial, Paulo Freire, Y.B. Mangunwijaya, Yogyakarta: Logung Pustaka.

Zakiyuddin Baidhawy, 2005, Pendidikan Agama Berwawasan Multikultural, Jakarta: Erlangga. 